\title{
Optimization Protocol of DNA Isolation and PCR in Muskmelon (Cucumis melo L.) by RAPD Marker
}

\author{
Jotshana Manik Maske*, Rajput Charansing Amarsing and Zote Rahul Keshavrao \\ Department of Plant Biotechnology SDMVM's College of Agricultural Biotechnology, Georai \\ Tanda, Paithan Road, Aurangabad (M.S.)-431001, India \\ *Corresponding author
}

\section{A B S T R A C T}

\begin{tabular}{|l|}
\hline Ke y w or d s \\
DNA, PCR, \\
Muskmelon, RAPD \\
\hline Article Info \\
\hline $\begin{array}{l}\text { Accepted: } \\
\text { 20 April } 2018 \\
\text { Available Online: } \\
\text { 10 May } 2018\end{array}$ \\
\hline
\end{tabular}

The present investigation entitled "Optimization Protocol of DNA isolation and PCR in Muskmelon (Cucumis melo L.) by RAPD Marker" was carried out at Department of Plant Biotechnology SDMVM's College of Agricultural Biotechnology, Georai Tanda, Paithan Road, Aurangabad (M.S.), 431001. Six different commercial verities of muskmelon plant were studied for this research. Standardization protocol of DNA isolation from muskmelon - One method (CTAB) was studied for obtaining good quality DNA from muskmelon. It is showing that when C-TAB method were used good quality of DNA obtained and its quantity 100ng. When C-TAB method used for isolation of DNA from Muskmelon, three extraction buffers were used for optimizing condition for DNA isolation from C-TAB method. Five primers were used for testing polymorphism and monomorphism percentage. Out of five primer A14 primer showed $22.22 \%$ polymorphism and remaining primer showed monomorphism. Total primer showed $4.1 \%$ polymorphism and $95.10 \%$ monomorphism.

\section{Introduction}

In India is usually called kharbuja. Melons, Cucumis melo L., are important horticultural crops in tropical and subtropical regions, which are also grown extensively in temperate climates. Muskmelon (Cucumis melo) is a species of melon that has been developed into many cultivated varieties. Muskmelon is native to Iran, Anatolia, Armenia, and adjacent areas on the west and the east which is believed to be their center of origin and development, with a secondary center including the northwest provinces of India and Afghanistan. Although truly wild forms of $C$. melo have not been found, several related wild species have been noted in those regions. The muskmelon contains minerals like potassium, sodium and magnesium and vitamin $\mathrm{A}, \mathrm{B}$ and C. It is also an excellent source of the antioxidant vitamin $\mathrm{C}$. Fruit of muskmelon is an excellent source of Vitamin A, (100 g provides $3382 \mathrm{IU}$ or about $112 \%$ of recommended daily levels) one of the highest among cucurbita fruits. Vitamin $\mathrm{A}$ is a powerful antioxidant and is essential for healthy vision. It is also required for maintaining healthy mucus membranes and skin. Consumption of natural fruits rich in vitamin $\mathrm{A}$ has been known to help protect 
from lung and oral cavity cancers. It is also rich in antioxidant flavonoids such as betacarotene, lutein, Zea-xanthin and cryptoxanthin. Potassium is an important component of cell and body fluids and helps control heart rate and blood pressure. It thus offers protection against stroke, and coronary heart diseases. Molecular marker is a gene or DNA sequence with a known location on a chromosome that can be used to identify individuals or species. They are identifiable DNA sequence, found at specific locations of the genome, and transmitted by the standard laws of inheritance from one generation to the next generation. Number of Fruit crop utilization and conservation has attracted global attention. Several of these fruit crop belonging from cucumber family contain exceptionally high amounts of polysaccharides, polyphenols, tannins, hydrocolloids (sugars and carragenans) and other secondary metabolites such as alkaloids, flavonoids phenols, terpenes and quinines which would interfere with the DNA isolation procedures. The problems encountered in the isolation and purification of DNA include degradation of DNA due to endonucleases, isolation of highly viscous polysaccharides, inhibitor compounds like polyphenols and other secondary metabolites which directly or indirectly interfere with the enzymatic reactions. Present investigation was carried out with an objective 1 . To standardize protocol for DNA isolation from muskmelon 2) To Optimize PCR protocol for RAPD marker in muskmelon.

\section{Materials and Methods}

The present study "Optimization Protocol of DNA isolation and PCR in Muskmelon (Cucumis melo L.) by RAPD Marker" was carried out at Department of Plant Biotechnology SDMVM's College of Agricultural Biotechnology, Georai Tanda, Paithan Road, Aurangabad (M.S.), 431001 during Jan. 2014 to May 2014. Six different commercial of different verities of muskmelon plant were used. Six healthy seeds of each variety were selected and sown in pots. At every two days interval germination was observed. After two weeks, fresh and young leaves were taken out, washed, weighed and crushed in liquid nitrogen to fine powder. Crushing of leaves was done by prechilled pestle and mortar in liquid nitrogen and care was taken to avoid thawing of the material. Before thawing the material was transferred into $50 \mathrm{ml}$ centrifuge tube and kept at$20^{\circ} \mathrm{C}$. Chemicals used for present study were of good quality (AR-grade) from various agencies.

\section{Extraction of DNA}

\section{Reagents used for the DNA isolation}

I. Extraction buffer:

1 gm CTAB

$3 \mathrm{M}(17.532 \mathrm{gm}) \mathrm{NaCI}$

$50 \mathrm{mM}(0.05 \mu \mathrm{l})$ EDTA

$100 \mathrm{mM}$ Tris-CI

$50 \mu 1 \beta$ - mercaptoethanol (added at the time of use).

The extraction buffer was autoclaved before addition of $\beta$-mercaptoethanol.

II. Chloroform: Isoamyl alcohol (24:1)

III. $100 \%$ Isopropanol (Ice-cold)

IV. Wash buffer: $70 \%$ ethanol

V. TE buffer (10 mMTris and $1 \mathrm{mM}$ EDTA, $\mathrm{pH}$ 8.0) Autoclaved before use.

Reagents used for PCR and gel preparation

Template DNA: $2 \mu 1$ (30ng) from muskmelon seedlings. 
RAPD primers

TaqDNA polymerase $(5 \mathrm{U} / \mu \mathrm{l})$

$10 \mathrm{X}$ Taq assay buffer with $\mathrm{MgCI}_{2}(15 \mathrm{mM})$

Tris $\mathrm{HCl} 1 \mathrm{M}(3.152 \mathrm{gm})$

Boric acid 1M (12.36) gm

EDTA $25 \mathrm{mM}$ (1.86) gm

$25 \mathrm{mM} \mathrm{MgCI}_{2}$

dNTP (10mM)

Sterile distilled water

$6 \mathrm{X}$ gel loading dye $(0.04 \%$ bromophenol blue, $0.04 \%$ xylene cyanol FF, $5 \%$ glycerol in water).

Ethidium bromide $(0.5 \mathrm{mg} / \mathrm{ml})$

Agarose

\section{Loading dye preparation}

Bromophenol blue, Xylene cylon, glycerol

\section{Buffers and solutions}

Different buffers and solutions used along with their composition are given in Table 1.

\section{RAPD-PCR analysis:}

\section{PCR Reaction mix (Master Mix)}

\section{Procedure for $\mathrm{PCR}$ reaction}

Sterile micro centrifuge tubes were numbered and placed on PCR tube stand.

At first $2 \mu 1$ of DNA was added to each PCR tube followed by master mix.

Then $1.5 \mu \mathrm{l}$ of each forward and reverse primer were added in each PCR tube.

The samples were mixed by brief centrifugation to bring down the content of tube.
PCRs were run on the programmable thermal cycler with the following PCR reactions:

\section{Results and Discussion}

Standardization protocol of DNA isolation from muskmelon - one method (CTAB) was studied for obtaining good quality DNA from muskmelon. It is showing that when C-TAB method were used good quality of DNA obtained and its quantity 100ng. When C-TAB method used for isolation of DNA from Muskmelon, three extraction buffers were used for optimizing condition for DNA isolation from C-TAB method (Table 2).

From table 3 is showing that when extraction buffer 1 was used for isolation of DNA from leaf sample of muskmelon about $80 \mathrm{ng}$ of DNA were obtained and it was contaminated with RNA and DNA.

In extraction buffer 1 PVP was not used and muskmelon contains secondary metabolite, small quantity of phenolic substance, sticky substance etc. because of this pellet obtained it was contaminated with carbohydrate and protein.

When extraction buffer 2 was used about 90ng of DNA was obtained here PVP was used and concentration of C-TAB also changed up to 1.5 gm DNA obtained was less contaminated compare to Extraction buffer 2.

From table 4 it is showed that fours primers were used for testing polymorphism and monomorphism percentage. Out of five primer A14 primer showed $22.22 \%$ polymorphism and remaining primer showed monomorphism. Total primer showed 4.1\% polymorphism and $95.10 \%$ monomorphism.

Molecular marker is a gene or DNA sequence with a known location on a chromosome that can be used to identify individuals or species (Table 5). 
Table.1 Composition of different buffers and solutions

\begin{tabular}{|c|c|c|}
\hline Sr. No. & $\begin{array}{l}\text { Buffer and } \\
\text { Solution }\end{array}$ & Composition \\
\hline \multicolumn{3}{|l|}{ Buffers } \\
\hline 1. & Extraction Buffer & 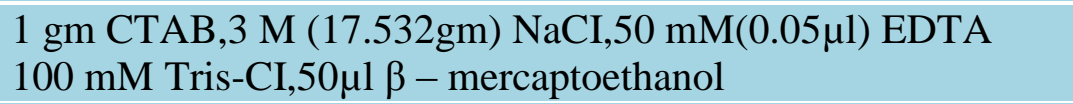 \\
\hline 2. & $10 \times \mathrm{TBE}$ & $0.9 \mathrm{M}$ Tris base, $0.9 \mathrm{M}$ Boric acid, 0.32 M EDTA \\
\hline 3. & TE Buffer & $10 \mathrm{mM}$ Tris $\mathrm{HCI}(\mathrm{pH} 8.0), 1 \mathrm{mM} \mathrm{Na}_{2}$ EDTA (pH 8.0) \\
\hline \multicolumn{3}{|c|}{ Solutions } \\
\hline 1. & $0.5 \mathrm{M}$ EDTA $\mathrm{Na}_{2}$ & $\begin{array}{l}3.72 \mathrm{~g} \text { EDTA dissolved in distilled water by stirring vigorously } \\
\text { and } \mathrm{pH} \text { was adjusted to } 8.0 \text { with NaOH. Total volume was } \\
\text { made up to } 100 \mathrm{ml} \text {. Solution was sterilized by autoclaving. }\end{array}$ \\
\hline 2. & Ethidium Bromide & $\begin{array}{l}1 \mathrm{~g} \text { Ethidium Bromide dissolved in distilled water and stirred } \\
\text { for few hours to ensure that the dye has dissolved and vol. } \\
\text { made up to } 100 \mathrm{ml} \text {. The container was wrapped in aluminum } \\
\text { foil and stored at } 4^{\circ} \mathrm{C} \text {. }\end{array}$ \\
\hline 3. & $5 \mathrm{M} \mathrm{NaCl}$ & $\begin{array}{l}1.752 \mathrm{~g} \text { of } \mathrm{NaCl} \text { dissolved in distilled water and volume } \\
\text { adjusted to } 100 \mathrm{ml} \text { with distilled water and solution was } \\
\text { sterilized by autoclaving. }\end{array}$ \\
\hline 4. & $1 \mathrm{M}$ Tris HCI & $\begin{array}{l}0.788 \mathrm{~g} \text { of Tris base was dissolved in distilled water by stirring } \\
\text { vigorously and } \mathrm{pH} \text { was adjusted to } 8.0 \mathrm{by} \text { adding concentrated } \\
\text { HCI. The volume was adjusted to } 100 \mathrm{ml} \text { with distilled water } \\
\text { and solution was sterilized by autoclaving. }\end{array}$ \\
\hline
\end{tabular}

Table.2 Total volume of PCR reaction mix was made to $25 \mu 1$ of which $22.0 \mu 1$ was master and remaining $3 \mu 1$ was the individual DNA of the genotype

\begin{tabular}{|l|c|}
\multicolumn{1}{|c|}{ Master Mix } & $1 \mathrm{x}$ \\
\hline $10 \mathrm{x} \mathrm{Taq}$ polymerase assay buffer with $\mathrm{MgCl}_{2}$ & $2.5 \mu \mathrm{l}$ \\
\hline $\mathrm{MgCl}_{2}(25 \mathrm{mM})$ & $1.5 \mu \mathrm{l}$ \\
\hline $\mathrm{dNTPs}(10 \mathrm{mM})$ & $0.25 \mu \mathrm{l}$ \\
\hline Taq polymerase $(5 \mathrm{U} / \mu \mathrm{l})$ & $0.067 \mu \mathrm{l}$ \\
\hline Sterile distilled water & $15.68 \mu \mathrm{l}$ \\
\hline
\end{tabular}

Table.3 Extraction buffer used for optimizing condition for DNA isolation by using C-TAB method

\begin{tabular}{|c|c|c|c|}
\hline Sr. No & Method & Extraction Buffer & $\begin{array}{c}\text { Quantity DNA } \\
\text { obtained }\end{array}$ \\
\hline 1 & \multirow{2}{*}{ C-TAB } & Extraction Buffer 1 & $\begin{array}{c}80 \mathrm{ng} \\
\text { (contaminated) }\end{array}$ \\
\hline 2 & & Extraction Buffer 2 & $90 \mathrm{ng}$ \\
\hline 3 & & Extraction Buffer 3 & $100 \mathrm{ng}$ \\
\hline
\end{tabular}


Table.4 Optimization of the RAPD-PCR reaction parameters for Muskmelon

\begin{tabular}{|c|c|c|c|}
\hline PCR Parameter & Tested range & $\begin{array}{l}\text { Optimum } \\
\text { conditions }\end{array}$ & Remarks \\
\hline $\begin{array}{l}\text { DNA } \\
\text { concentration (ng) }\end{array}$ & $\begin{array}{l}5,10,40,50,75 \\
100\end{array}$ & $75 \mathrm{ng}$ & $\begin{array}{l}\text { Absence of } \\
\text { amplification with } \\
\text { lower concentration and } \\
\text { presence of smear at } \\
\text { higher concentration } \\
\text { affected the } \\
\text { repeatability. }\end{array}$ \\
\hline $\begin{array}{l}\text { Magnesium } \\
\text { chloride }(\mathrm{mM})\end{array}$ & $1,2,3,4$ & $3 \mathrm{mM}$ & $\begin{array}{l}\text { Excess/lower } \\
\text { concentration increases } \\
\text { the non-specificity and } \\
\text { yield of the product. }\end{array}$ \\
\hline $\begin{array}{l}\text { Deoxynucleotide } \\
\text { triphosphates } \\
\text { (dNTPs) (mM) }\end{array}$ & $0.1,0.2,0.3$ & $0.2 \mathrm{mM}$ & $\begin{array}{l}\text { Increased concentration } \\
\text { reduces the free } \mathrm{Mg} 2+\text {, } \\
\text { interfering with the } \\
\text { enzyme }\end{array}$ \\
\hline $\begin{array}{l}\text { Primer } \\
\text { concentration } \\
(\mu \mathrm{M})\end{array}$ & $0.1,0.5,1$ & $0.5 \mu \mathrm{M}$ & $\begin{array}{l}\text { Lower and higher } \\
\text { concentrations lead to } \\
\text { absence of amplification } \\
\text { and primer dimer } \\
\text { formation, respectively. }\end{array}$ \\
\hline $\begin{array}{l}\text { Taq polymerase } \\
\text { (units) }\end{array}$ & $0.1,0.2,0.5,1.0$ & $0.2 \mathrm{U}$ & $\begin{array}{l}\text { Lower concentration did } \\
\text { not show proper } \\
\text { amplification. High } \\
\text { concentration showed } \\
\text { decreased specificity. }\end{array}$ \\
\hline $\begin{array}{l}\text { Annealing } \\
\text { temperature }\left({ }^{\circ} \mathbf{C}\right) /\end{array}$ & $\begin{array}{l}25,30,35,37,65 \\
\text { and } 70\end{array}$ & $37^{\circ} \mathrm{C}$ for $60 \mathrm{~s}$ & $\begin{array}{l}\text { Higher/lower annealing } \\
\text { temperatures (from } \\
\text { optimum) results in } \\
\text { difference in specificity }\end{array}$ \\
\hline Number of cycles & $25,30,35$ and 50 & 30 & $\begin{array}{l}\text { Higher/lower cycles } \\
\text { (from optimum) effects } \\
\text { the amplification }\end{array}$ \\
\hline
\end{tabular}

Table.5 Monomorphism and polymorphism \% in muskmelon

\begin{tabular}{|c|c|c|c|}
\hline Sr. No & Primer & Primer Sequence & Band Size (bp) \\
\hline $\mathbf{1})$ & A04 & AATCGGGCTG & $300-200$ \\
\hline 2) & A05 & AGGGGTCTTG & $300-950$ \\
\hline 3$)$ & A07 & GAAACGGGTG & 500 \\
\hline $\mathbf{4})$ & A08 & GTGACGTAGG & $200-150$ \\
\hline 5) & A14 & AGGGGTCTTG & $300-950$ \\
\hline
\end{tabular}


Fig.1 RAPD banding pattern of muskmelon

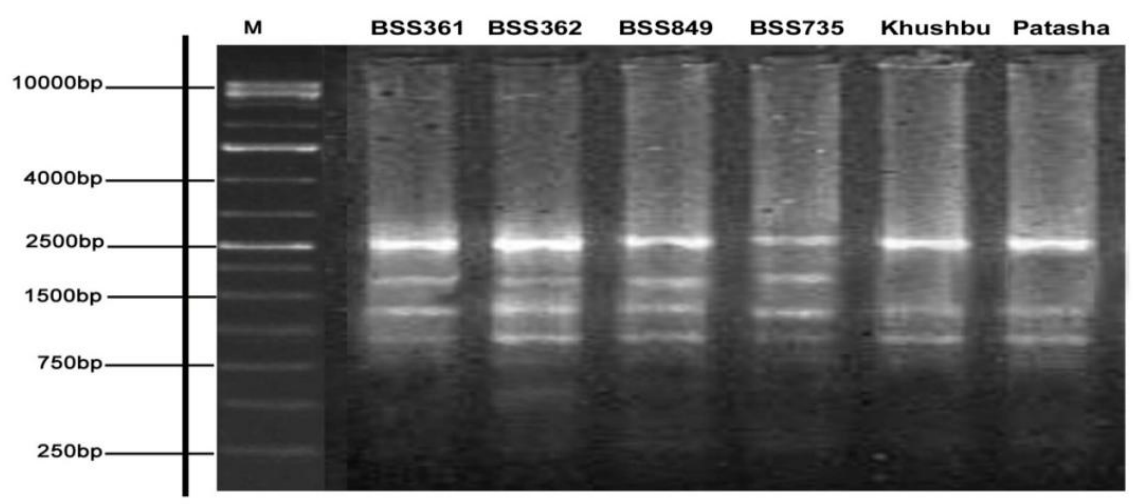

Plate 1 RAPD banding pattern of Muskmelone using A08

They are identifiable DNA sequence, found at specific locations of the genome, and transmitted by the standard laws of inheritance from one generation to the next generation. Five primers were used for testing polymorphism and monomorphism percentage. Out of five primer A14 primer showed $22.22 \%$ polymorphism and remaining primer showed monomorphism. Total primer showed $4.1 \%$ polymorphism and $95.10 \%$ monomorphism (Fig. 1).

From present investigation it is concluded that optimize condition for DNA isolation and PCR analysis required for obtaining accurate result. Pure quality of DNA require for number of studies undertaken in molecular marker technology like phylogenetic study, DNA fingerprinting, linkage mapping etc. Therefore if we have standardized protocol of DNA isolation and PCR analysis then it plays an important role for molecular studies.

\section{References}

Daning-Poleg Y, et al., Development and characterization of microsatellite markers in Cucumis. TheorAppl Genet 102:61-72
Daryono, B.S. and K.T. Natsuaki. 2002. Application of random amplified polymorphic DNA markers for detection of resistant cultivars of melon (Cucumis melo L.) against cucurbit viruses. Acta Horticult, 588, 321-329.

Daryono, B.S. et al., K. Wakui and K.T. Natsuaki. 2009. Development of random amplified polymorphism DNA markers linked to CMV-B2 resistance gene in melon. Hayati J. Biosci., 16 (4), 142-146.

Kannaiyan, S.and Prasad N.N 1975. Influence of foliar nutrient sprays on population of fusarium oxysporum f.sp.melonis and other soil microflora in rhizosphere of muskmelon. Indian phytopathol. 27: 527:531

Lo'pez-Sese' AI et al., Estimation of between and within accession variation in selected Spanish melon germplasm using RAPD and SSR markers to assess strategies for large collection evaluation. Euphytica 127:41-51

Sebastian $\mathrm{P}$ et al., Cucumber (Cucumis sativus) and melon ( $C$. melo) have numerous wild relatives in Asia and Australia, and the sister species of melon is from Australia. 
ProcNatlAcadSci USA 107: 142691427.

Staub, J.E. et al., comparion and analysis of cultivated melon group (Cucumis melo L) using random amplifed polymorphic DNA and simple sequence repeat maker. Euphytica 115: 225:241.
Tzitzikas EN et al., Genetic diversity and population structure of traditional Greek and Cypriot melon cultigens (Cucumis melo L.) based on simple sequence repeat variability. Hortscience 44(7): $1820-1824$.

\section{How to cite this article:}

Jotshana Manik Maske, Rajput Charansing Amarsing and Zote Rahul Keshavrao. 2018. Optimazation Protocol of DNA Isolation and PCR in Muskmelon (Cucumis melo L.) by RAPD Marker. Int.J.Curr.Microbiol.App.Sci. 7(05): 2678-2684.

doi: https://doi.org/10.20546/ijcmas.2018.705.310 